\title{
橋核とその線維結合
}

\author{
Tractus Pulvino-pontinus を中心として
}

石井 朗 夫*

橋はその横断面では，背部と底部との 2 部か ら成り，橋背部は古く，橋底部は新しい部分で ある。橋底部は大脳皮質及び小脳の発達に伴っ て生じた新しい部分であり，それらとの解剖生 理学的関係については古くから可成り解明され てさたが 1-8)，それ以外の領域との関係につい ては報告が少ない，その中でも，1890年，Held 9）が報告した視蓋橋路（Tr. tectopontinus）は 有名なものであるが，近年，Brodal らは，橋 と小脳との間の 新しい関係 (Sunderland. 1940 7), Brodal-Jansen 194610)), 春䯣からの上行性 線維の存在 (Walberg-Brodal 195311) を報告 乙，橋核が今迄以上に重要な機能を有する可能 を性を強調している。また，1966年，益田等 12$)$ 13)は，体温調節中枢としての視束前域（Preoptic region）から橋核に至る視束前部橋路（Tr. preotico-pontinus）を報告している。

今回 著者は，間脳と中脳との境を，1側性 に，大脳脚を傷つけることなく破壞したとこ ろ，内側毛帯を貫いて橋核に至る興味ある変性 線維群を認めた。そこでその起始, 経路を調べ るために, 片側の上丘, 大脳皮質, 後頭葉, 及 び間脳から中脳にかけて種々の部位に傷を作 り，それによって生じた種々の変性線維群と比 較検討した。更に，その終止領域を確認するた めに，橋核の分類について再検を試みた。その 結果, この線維群が, Thalamus の一部から下 行し橋核に至る新しい線維群であることが判明 したので報告する。な特，染色法としては， Nauta-Gygax 法 14)を用いた完全連続標本で詳

\footnotetext{
* 順天堂大学助手 (解剖学)
}

昭和43年9月13日受付
細に検討したものである。

\section{I 橋核について}

橋核は，古典的には一続きの大きな灰白質と 考克られていたが，Bechterew (1885) 15) が始 めてこれを内側と外側とに分けて以来，幾多の 研究により，多数の核群から成立っていること が明らかとなった，そのらら特に家鬼橋核に関 するものとしては，Borowiecki (1911) 16) の 比較解剖学的及び実験的研究を始めとして, Winkler-Potter (1911) 17), Brodal-Jansen (1946) 10), Olszewski-Messen (1949)18) らの研究があ る。このうち, Borowiecki, Brodal一派らに よる分類は，形態と機能を結びっけたすぐれた 分類であると思われる，ところで著者は，後述 する新しい線維群に関する諸実験の中で, 橋核 の終止領域を検討しているうちに，橋核の形態 的分類について若干の知見が得られたと考党 る. 以下, 従来の分類との相違点に重点を特い て述べることとする。

〔材料と方法〕

材料として成熟カイウサギ (OrytolagusCuniculus var. domesticus) の脳を死後直ちに 頭蓋腔から摘出し, 純アルコール液で固定し, ツェロイジン包埋の後, 厚さ $30 \mu$ の前額断完 全連続切片を作製し, Niss1 氏染色变法で細胞 染色を行つた。その他, 教室所蔵の Pal-carmin 染色のカイウサギ脳完全連続切片標本も参考に した。

分類方法として，細胞形態，分布状態，位置 
関係を基準とした。

命名法は，橋底部を貫く橋縦束を中心とし $\tau$, 内側, 外側, 背側, 背外側飞, 昰た, 橋の 全体的位置関係少ら正中部, 腹部, 前, 後とい ら表現を用いた。な招，橋底部の灰白質につい てのみ検討した。

\section{〔所見及び考按】}

1) 前内側核 Nucleus medialis anterior (Ph. 1, 2)

細胞質に富み，大きな Nissl 顆粒を有する 大きな細胞で，形態的に運動性細胞飞似て特 り，長い神経突起を有する細胞によって辁成さ れている (Ph. 2 の矢印).

この細胞群は橋の前端から縦束の腹内方に出 現し，橋の前方 $1 / 3$ の高さ附近に及ぶ. その長 軸は，前腹方から背方に向う。前額断切片で は. 縦束の内方に扇状に拡がる(Ph. 1 の矢印). 中心部には, 前述の特徵的細胞が多く, 周辺部 に至ると，やや小さい濃染性の細胞が多い，前 端近くでは, 内方に正中核, 外方は縦束周囲核 と接する。後方に進むと, 正中核との間, 前内 側核の腹方, 及び縦束周囲核との間に後内側核 の細胞群が現れ，次第に背方に向って增大する ために，前内側核は，内側毛帯と縦束とによっ て作られる三角地帯に限局されつつ次第に縮少 し，橋の前 $1 / 3$ の高さよりやや後方で完全に消 失する.この核は Borowiecki の paramedialkern, Brodal の paramedial gray 等の前方 1/3の領域である. 後述する Tractus pulvincpontinus は主としてこの核に終末する. 又 Brodal-Jansen 10) によれば，鬼及び猫の小脳前 葉の lateral hemisphereal division は paramedian gray の rostral ないしは前方 $1 / 3$ の領 域, 即方著者の Nucleus medialis anterior か ら線維を受けていると報告している，以上綜合 して考えると, 従来示されて来た橋緃束の内側 飞拡がる核は，前後に拡がる一続きの核ではな く, 形態的, 機能的両面から, 前後の 2 核に分 けられ得るものと考觉る。
2) 後内側核 Nucleus medialis posterior (Ph. 3-7)

従来, 橋縦束の内側に拡がる核として, para一 medial nucleus (Mingazzini, Borowiecki), paramedial gray (Brodal et al.), Nucleus medialis (Winkler-Potter) 等と呼ばれた領域の後 方 $2 / 3$ の領域にあたる。構成細胞は, 従来の記 載と一致する。橋のやや前方の高さで, 腹側核 の両側に, 特に細胞の密集した領域が存在する (Ph. 4 の Pl. Pm). 後頭葉を破壊すると主に この部に終末変性が認められる。然し, 細胞形 態の上ふら，後内側核の細胞と区別することは できない (Ph. 5, 6). 又後方領域では，内側 毛带の辺縁で, 被蓋部の 細胞 (Nucleus tegmenti pontis）と一続さとなり，形態的に両者 を区別することができない(Ph.7).

\section{3) 正中核 Nucleus medianus (Ph. 8-10)}

卵円形の小さな細胞によって構成される細胞 集団で (Ph. 8, 9), 橋前半の高さでその正中部 に存在する. Borowiecki, Brodal らによれば, この部の細胞の形態的特徵として, 紡錐形の小 型細胞でその長軸を背腹の方向に向けて配列し ていると述べているが (Ph. 10), 実際にはこ の種の細胞は，正中核の中にの久存在せず，橋 横線維群及び直線維群の走行に一致して認めら れるものである (Ph. 8). 正中核を構成するの は, 形態的には, 卵円形の小さな細胞のみであ る.

4) 腹側核 Nucleus Ventralis (Ph. 11)

この核に関しては，従来諸家の間では異論が ない. Borowiecki の ventral Gruppe, Brodal の ventral gray, Winkler-Potter の Nucleus ventralis, Olszewski-Messen の subnucleus parvocelluralis と全く一致する.

5) 外側核 Nucleus lateralis (Ph. 12，13) 橋の前端附近から後端まで，前後に延びる。 前額断では, 橋縦束の外側部に, 牛角状に拡が る。この核は，これまでの諸家の意見と一致す る。 
6) 背外側核 Nucleus dorsolateralis

(Ph. 13, 14)

比較的大きな 細胞から成る (Ph. 14). 外側 核の背外方に，それよりやや遅れて出現し，後 方に進むと，橋縦束の背方縁に沿つて内方に延 び，後方に進むに 従つて縮少する (Ph. 13).

Borowiecki, Brodal らの同名核と一致する.

7) 橋縱束周囲核 Nucleus perifasciculi longitudinalis ( $\mathrm{Ph} .15,16)$

橋縦束の周囲及び線維間に存在する(Ph. 15) 中ないしはやや小さな長紡錐形の細胞集団であ る(Ph. 16)。細胞の長軸は縦束ないしは小線 維束の辺縁に平行に向う。橋前半の高さでは, 発達は悪いが，後半に至つて次第に增大し 2-3 層を形成する. Borowiecki の peripeduncular Gruppe, Brodal $の$ pedunclar gray $と$ - 致す る.

小括

橋核を形態的に分類し次の知見を得た。

1) 前内側核 Nucleus medialis anterior

橋縦束の内方でかつ橋の前方 $1 / 3$ の領域を占 め, 主として運動性細胞に似た特徴的形態を有 する大型の細胞の集団である.

2) 後内側核 Nucleus medialis posterior 前内側核の後方に位置し，橋の尾端まで拡が る. 主として中等大の細胞の集りである. 中央 の高さでは, 腹側核の両側に一部細胞の密集し た領域が存在する。形態的にこの部の細胞は後 内側核の細胞である.

3) 正中核 Nucleus medianus

卵円形の小型細胞の集団で，橋前半の高さで その正中部を占める。従来示されてきた紡錐形 小型細胞は，正中核のみに限局して存在するも のではなく，橋底部を縦横に走る橋線維群の間 に普く分布する。

4) 腹側核 Nucleus ventralis

橋の腹方に存在する小型細胞の久から成る細 胞群で, 諸家の分類と一致する.

5) 外側核 Nucleus lateralis

橋縦束の 外側部に存在する 細胞群である.
Borowiecki の lateral kern, Brodal の lateral gray に一致し, Winkler-Potter の Nucleus lateralis の一部にあたる。

6) 背外側核 Nucleus dorso-lateralis

比較的大きな細胞の集団である、橋縦束の背 外側部で, 外側核と混在しながら出現し, 後方 に進むと縮少する。. Borowiecki，Brodal の分 類と一致する.

7）橋縦束周囲核 Nucleus perifasciculi longitudinalis

橋縦束を取囲むやや小型の長紡錐形の細胞集 団である. 橋の前方の高さでは発育悪く, 後方 に進むに従って增大する。諸家の分類とほぼ一 致する。

\section{II 新しい線維群について}

\section{〔材料と方法〕}

40 匹の成熟カイウサギ（体重 $2500 \mathrm{~g}$ 以上） を用い，東大脳研式の脳破壊刺激装置で Nembutal 麻酔下に電気凝固巣を脳内各所に作っ た. 大脳皮質, 後頭葉は吸引ポンプで吸引除去 した。何れも術後 7 日目に，10\%中性ホルマリ ンを注入して殺し, 脳を摘出して 1 ケ月間ホル マリンで固定し， $25 \mu$ の前額断凍結連続切片を 作り，Nauta-Gygax 法の染色を施した。 その 他, 教室所蔵の Pal-carmin 染色及び Nissl 染 色の完全家鬼脳連続切片も使用した。

(所

見)

家鬼の実験例の中， 5 例に於て，視床枕から 橋核に至る線維を新たに追求することができ た. 今迄の研究方法と違って Nauta-Gygax 法 を用いたので，軸索変性及び終末变性がよく認 められ, 起始, 終止の決定もできた.

脳切片各部の名称は, Winkler-Potter の図 譜17)の命名をそのまま使用した。

1) 新しい線維群について

No. 13. (Fig. 1)

後交連の高さ，手綱核の寸ぐ外方から後腹方 飞 Pulvinal (以下 $\mathrm{Pu}$ 領域) の内側加中脳 


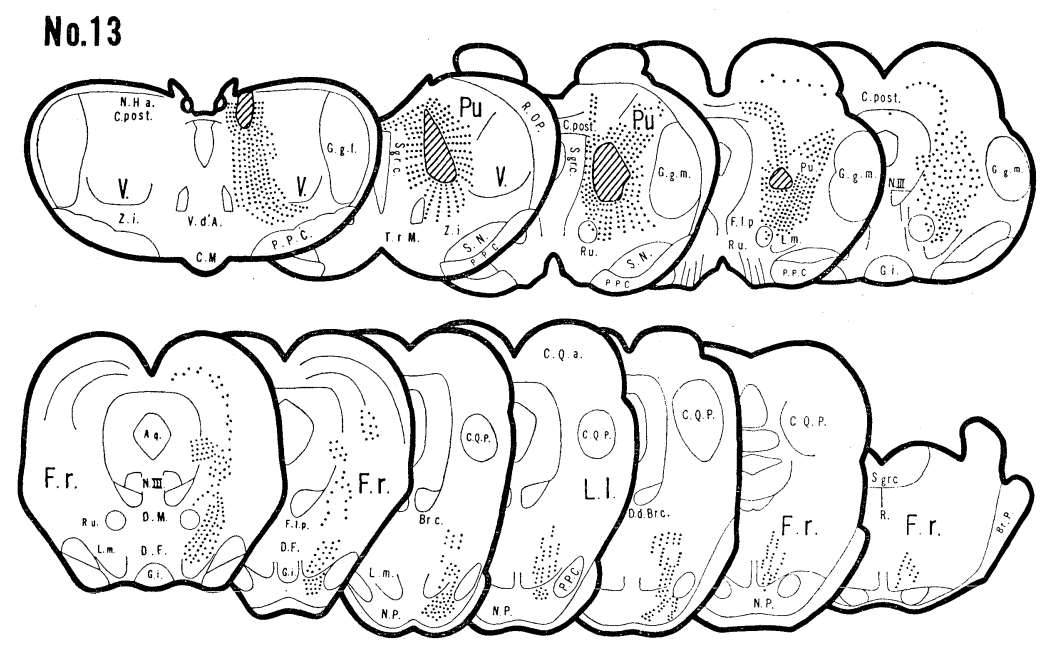

Fig. 1. Shematic drawings showing distribution and preterminal degenerations of the X-bundle in the brain stem following lesions of diencephalo-mesencephalic boundary.

The same time it shows accompanying degenerated bild.

The strippled areas incicate approximately the distribution of degenerated fibers and preterminal degenerations.

網様体に至る傷である。

この傷によって，視蓋脊㵦路は汪とんど変性 が認められず, 次に述べる線維束の変性が認め られた。 Pu 領域から弓状をなして腹外方に赤 核の外側を通り内側毛帯の外方を道ってこれを 貫き(Ph. 17, 18)，橋核に至る变性線維束が容 易に認められた。下丘の高さで脚間核のめる部 分では，この線維束は内側毛带を貫きながら橋 綎束の背内方から, 大部分は橋の前内側核に終 る $(\mathrm{Ph} .19,20)$. 一部は橋の中央の高さで後内 側核に終る。何孔も傷と同側に变性線維は走 り，反対側に向ら線維束は認められなかった (Ph. 21). これが新しく見出した線維群である. 以下この線維群を X-Bundle と表記する. 上 方手綱核に稘のある高さでは，そこからZona incertaに向ら变性線維束が認められたが，こ れは別の上行性線維束である.

2）間脳を破壞した場合

No. 2, (Fig. 2)

視床外側核, 視床枕, 視床内側核, 腹側核, 不確帯に傷を持つ例で, X-Bundle の变性線維 束が認められた。
No. 1 (Fig. 2)

この例では, 手綱核内側部, 外側部, 視床内 側核, 外側核腹側核, 不確帯から大脳脚に及心゙ 傷である、X-Bundle の変性は認めない。

No. 10 (Fig. 2)

手綱核，視床腹側核の一部を損傷した。この 例でも X-Bundle の変性は認められない。

No. 11 (Fig. 2)

前例よりやや前方の高さで, 主として視床腹 側核を大きく損傷した，X-Bundle は変性を起 さない，以上 4 例から視床枕 $(\mathrm{Pu})$ に傷が及 ぶか否かによって，X-Bundle の変性の有無が 決まると思われる。

3）中細網様体を破壞した場合

No. 7 (Fi. 3)

上丘前方の高さで 視床枕 $(\mathrm{Pu})$ の腹内側部, 内側㮏状体内側の網様体が損傷されている。こ の例では, X-Bundle は明らかに变性する。

No. 8 (Fig. 3)

上丘後方の高さで, 上丘から中脳被蓋の外側 部に及び下丘腕にも及ぶ傷がある。この実験例 でも X-Bundle が変性して認められる。即ら 
No.1

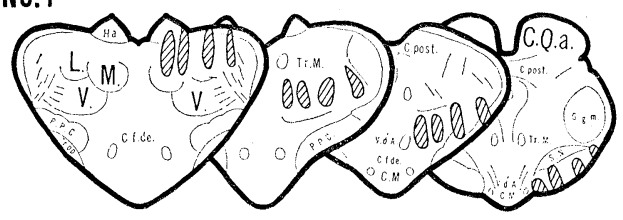

No.2
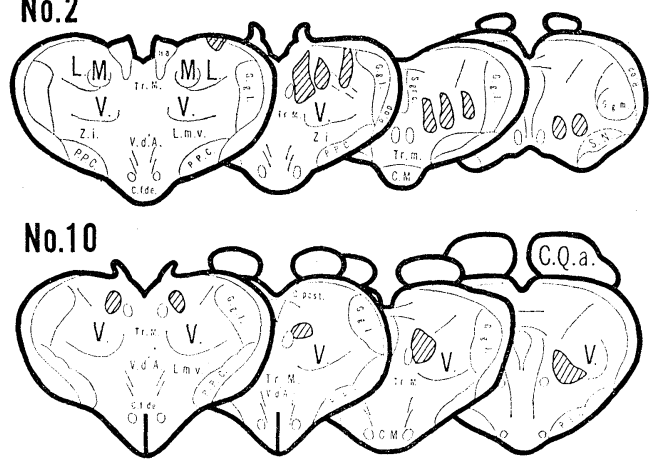

No.11

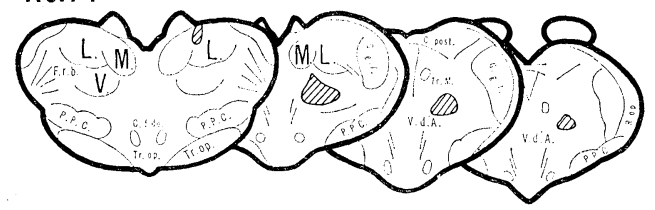

Fig. 2. Degenerated X-Bundle is noticed only in the case No. 2, which has the lesion of the pulvinal region. As a result of these finding it is defined that the degenerated X-Bundle appears when the Pulvinal region are destructed.

中脳被蓋外側部の傷で，上述の線維束が変性す る。

No. 9 (Fig. 3)

上丘中央の高さで，内側膝状体の内側の網㥞 体に限局した倠でめる。従って Pu 領域から 上丘の高さでは，網様体の外僛部を通り，下丘 の高さでは，内側毛帯を貫きながら，新しく認 められた線維束 X-Bundle は大部分橋の前内 側核，一部後内侧核に終末变性が認められた。

4）上丘との関係

次に上丘からの下行性線維束との関係につい てみると,橋核に至る線維群で有名なのは Held の視蓋橋路であり，その終末を確かめる意味で 上丘を破壊してみた。
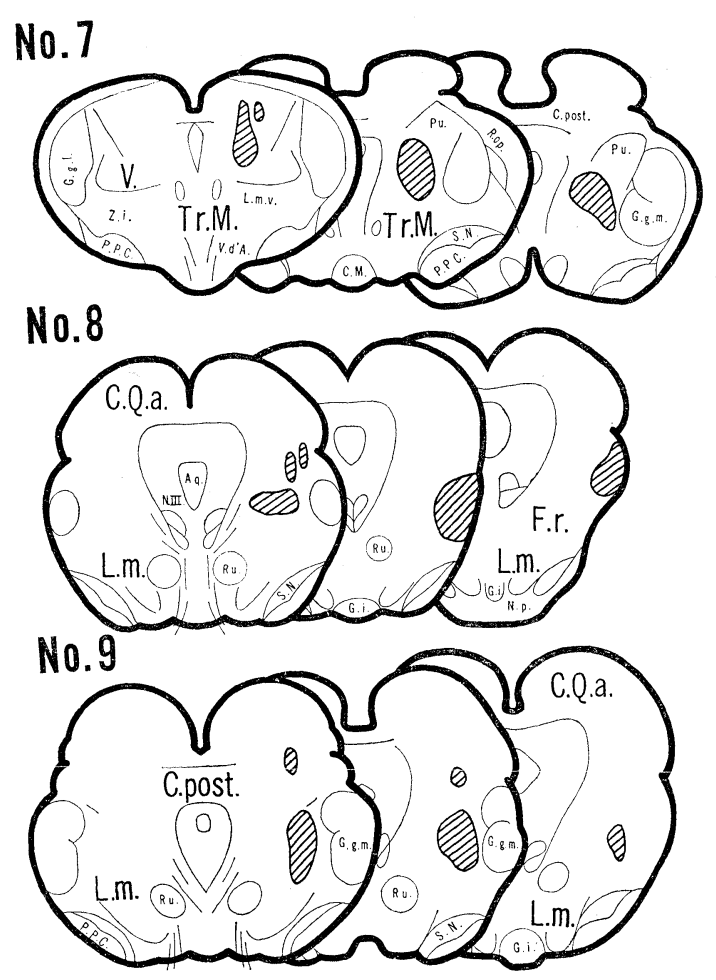

Fig. 3. Schematic drawings show the destructed area (shaded portion) in the dorsolateral part of the brain stem. In 3 cases, the degenerated $\mathrm{X}$-Bundle are noticed.

\section{No. 23 (Fig. 4)}

上丘に限局してその前方 $1 / 3$ を破壞し，中心 灰白質に及ばない傷である。

No. 21 (Fig. 4)

上丘の中 $1 / 3$ のところを，内方は中心兏白質 にかかる鹪である。

No. 20 (Fig. 4)

上丘の後 $1 / 3$ のところを下丘との移行部で網 様体との境を中心灰白質にかけて横に大きく拡 がる傷である.

これらの稘により，上丘では Stratum medullare superficialis, intermedius 及び profundum に変性が認められる。このうち，strātum intermedius から腹外方の被蓋部に变性線 維束がでる。この線維束は $\mathrm{Pu}$ の腹外方, 内 側膝状体の内方を通って，下丘の高さでは，外 


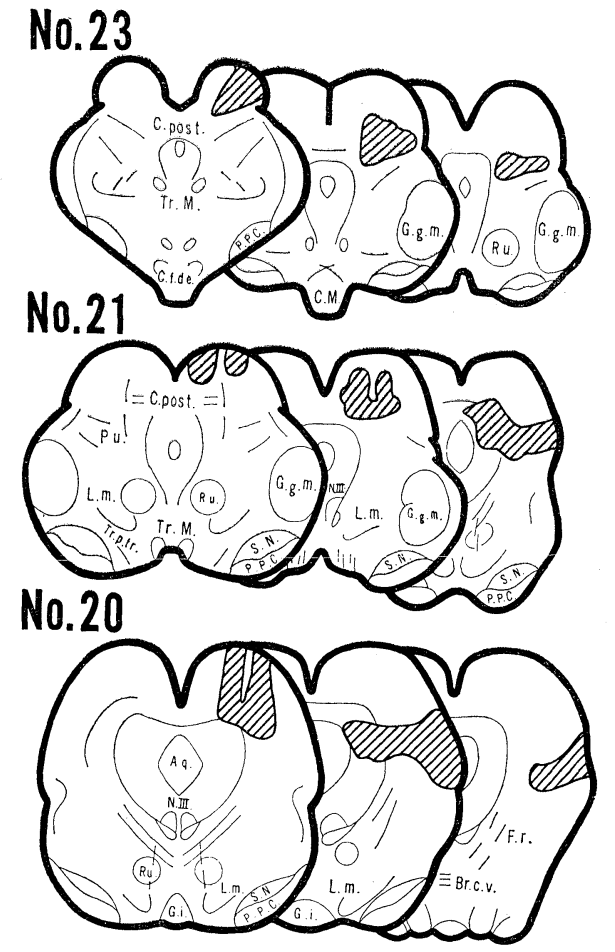

Fig. 4. Diagrams showing lesions of various part of the superior oolliculus and central gray substance.

側毛帯と下丘腕との間を通り，橋背部の外側縁 を通って橋灰白に向う(Ph. 22, 23)。一部は内 方に向い橋網様体に終る(Ph. 24)，これが視 蓋網様体路である. 前者の線維群の多くはその 部に 終末するが (Ph. 25)，一部の 線維は外側 核を貫いて 縦束周囲の 線維と共に内方に向ら (Ph. 26). 橋縦束から分れる線維は後頭葉の損 傷によるものである. 然し, その終末部は, 視 蓋橋路の終末部と区別し 難い(Ph. 27). 上丘 から下行する線維束のらち, 後縦束と赤核との 間を通って交叉して反対側を下降する視蓋春䯣 路もみられる.上丘から中心灰白質に入る短い 線維が 3 例とも認められた。 X-Bundle は上丘 破壊例では認められない，X-Bundle と視蓋橋 路との比較を Fig. 5 で模式的に示した.

5）大脳皮質との関係

大脳皮質半側切除と後頭葉除去を行い, 橋核
と大脳皮質との関係，後頭葉との関係を検討し た。

大脳皮質半側切除例は，3 例 (No. 130, No. 132，135）でいずれも深い損傷であるが，橋核 の变性は著明である。同側の橋核は凡て終末变 性が認められた。橋の縦束を中心に，变性線維 が放射状に拡がり，同側の橋核の細胞間に細く 分布して終っている。こ机で大脳皮質から橋核 に投射線維が至ることがいえる，尚いずれの例 もX-Bundle は認められないので，これは，皮 質下からの投射線維と考光られる。

後頭葉除去例の 3 例では (No. 118, No. 119, No. 120) 家鬼の脳回が浅いために, 後頭葉は, はっきりしないが，物よそ，Brodmann19) の分 類による Regio occipitalis (Area 17，18) を中 心とした領域を吸引除去して (Fig. 6), 頭頂後 頭橋路を追跡してみた，橋核での終止部位は 3 群に分けられる。即号，橋外側核に終るもの と, 後内側核の一部, 特に腹側核の両側の処に 終るものとがある．橋縦束の変性と共に，これ から外側核に向ら線維束がみられ，又橋縦束の 内方から後内側核に向う線維束は, 橋核前端部 で腹側核の内側と外側の領域に終る(Ph. 28). これらの変性線維束は, 橋縦束の中を通り, 然 るべき核群に終るが，X-Bundle は橋縦束の中 を通らず，異った核群，即ら前内側核に一致し た領域に終り，後頭橋路とも異るものである (Fig. 8, Fig. 5 と比較).

6) 中脳被蓋との関係

中脳の四丘体以外の領域との関係を吟味する ために，下の如き実験を行った。

中脳網様体の内側部の破壊は 3 例 (No. 12, No. 15, No. 24) で，損傷領域は Fig. 9 に示 した。これらの例では, X-Bundle は認められ ない。

7）内側膝状体との関係

内側膝状体の破壞は 3 例で， らら 1 例（No. 45）は内側膝状体と $\mathrm{Pu}$ 領域の一部が損傷され ている. この例で, X-Bundle の変性は著明で ある。 

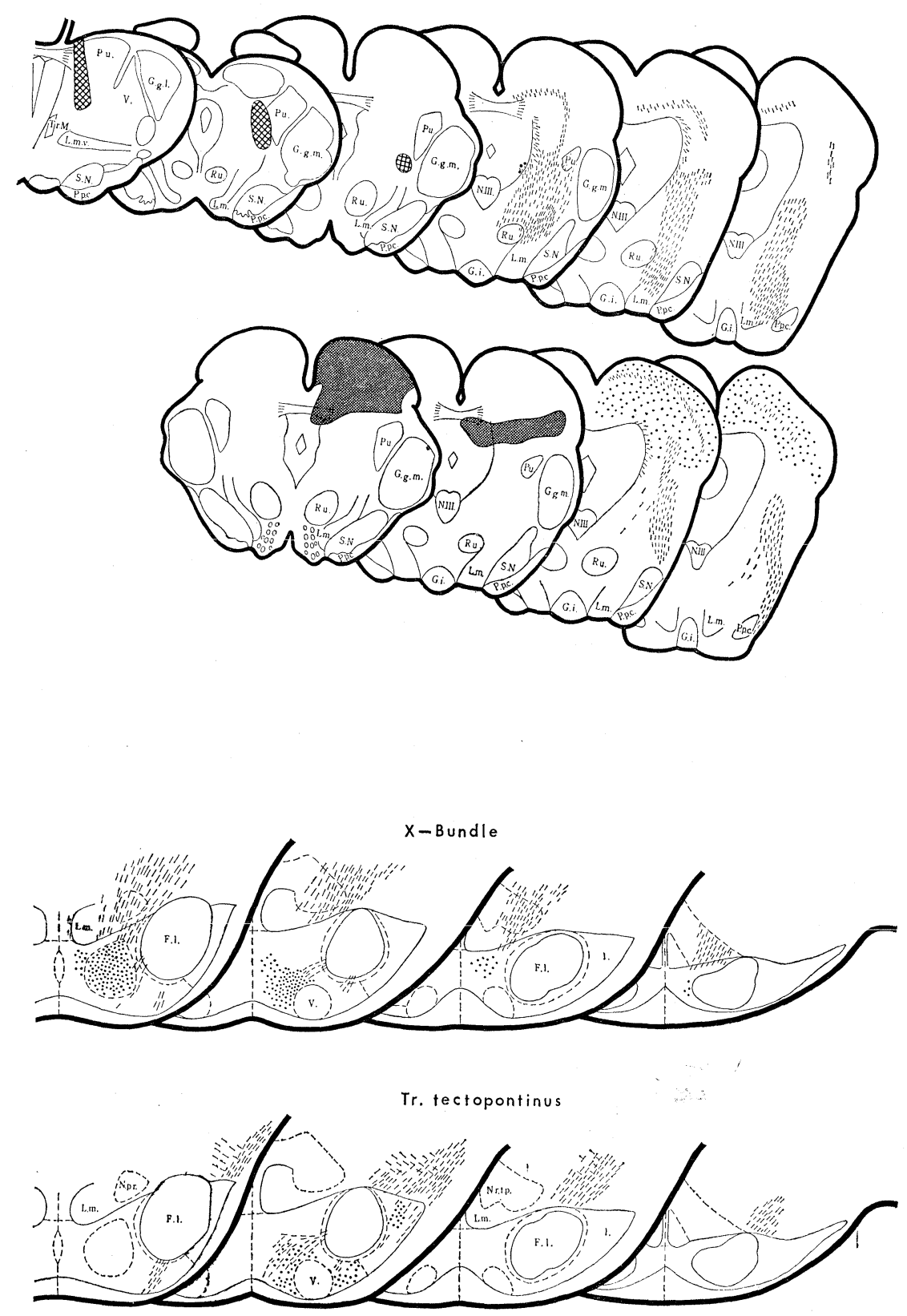

Fig. 5. Schematic drawing shows the course and the terminal region compared of the X-Bundle with of the tractus tecto-pontinus. Degenerated fibers are indicated by hacking and terminal degeneration by dots. 


\section{No.118}
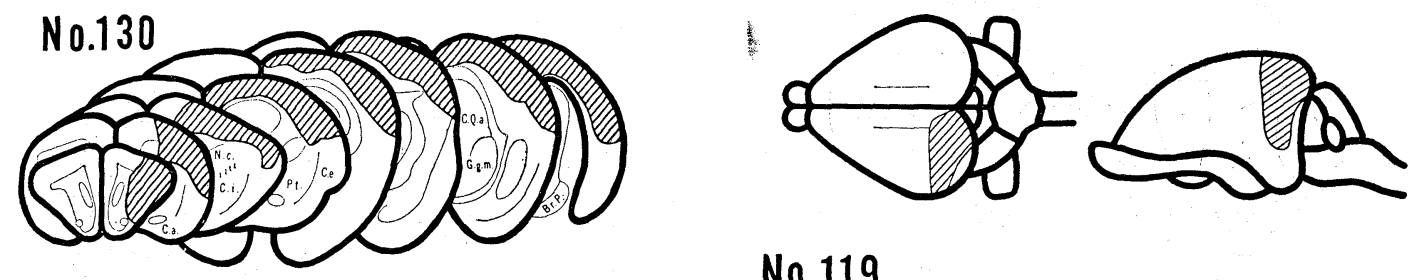

No. 119
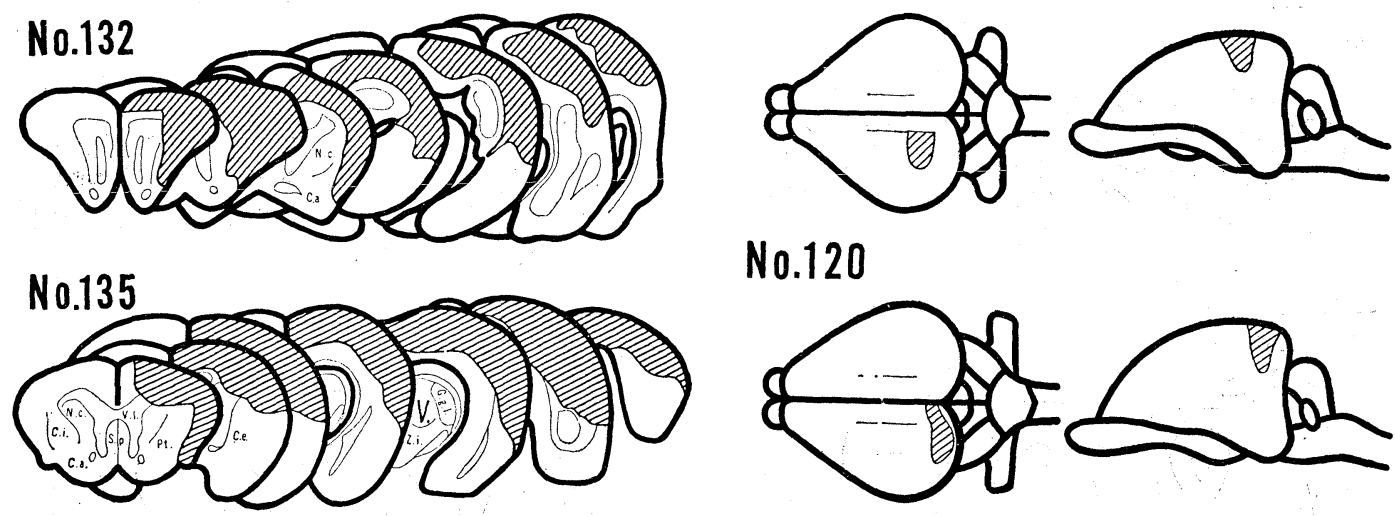

Fig. 6. Diagrams showing the hemisection. The shaded portion indicate destructed No.120 region.

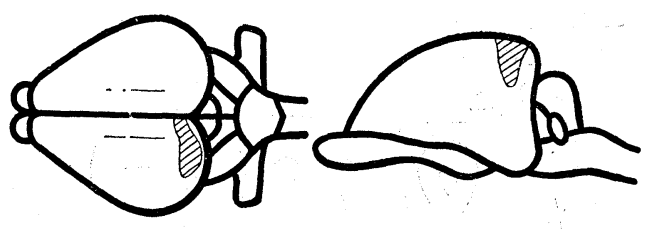

Fig. 7. Diagram showing the parieto-occipito lobotomy.

Tr.occipitopontinus

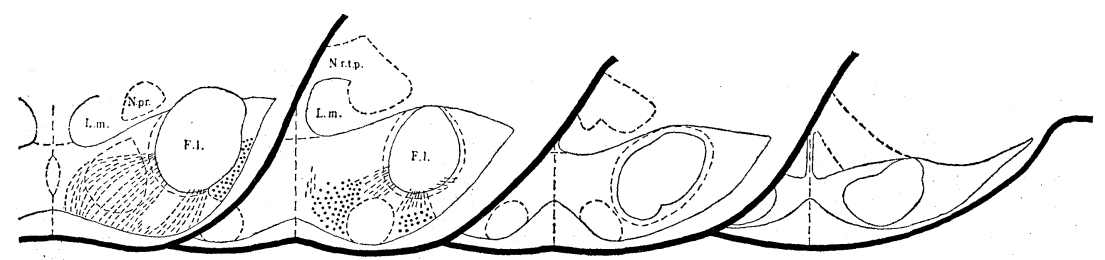

Fig. 8. Diagram showing the terminal degeneration of the Tractus occipito-pontinus. The hatching area indicate degenerated fibers and doted area indicates the degenerated area.

それに反し，残り 2 例（No. 43，44）では， 内側滕状体と, $\mathrm{Pu}$ 領域以外の隣接領域の一部 が破壊されているが，いずれも X-Bundle の 変性は認められない。従って X-Bundle は内 側膝状体とは無関係であるが，Pu 領域とは重 要な関係を持っているといえる。
小括

以上 40 数匹のカイウサギでの実験結果を， Nauta-Gygax 法で 軸索変性を 追求したので, 今迄の䯣鞾変性の Marchi 法と異り, 終末変性 る確められた。いろいろな傷で得られた結果を 綜合して，新しく得られた線維群は，Winkler- 


\section{No.12}
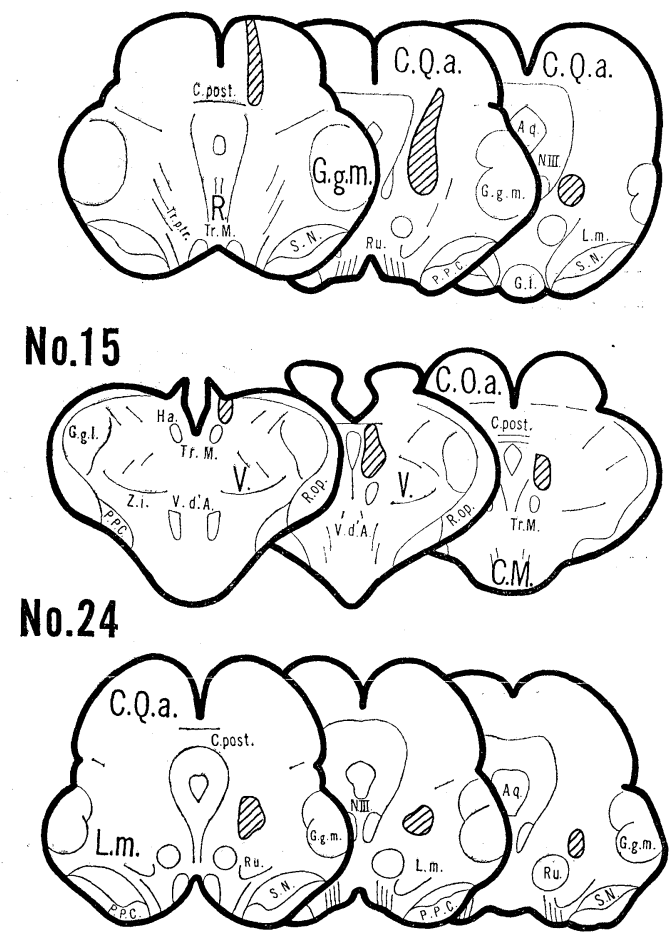

Fig. 9. Schematic drawings showing the destructed area (shaded area) in the dorsomedial portion of the tegmentum of the
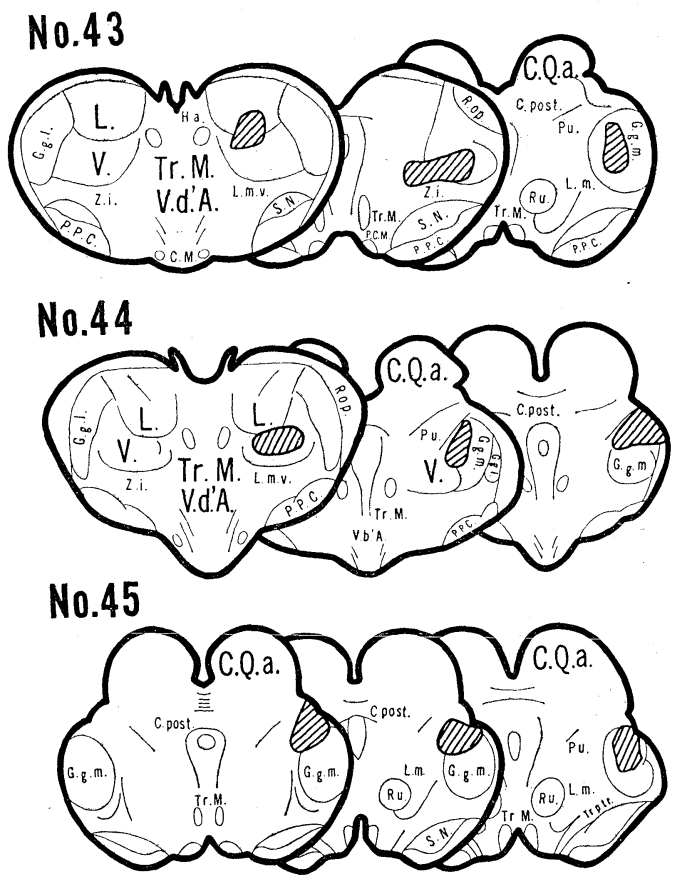

Fig. 10. Schematic drawings showing the destructed area at the level of the ganglion geniculatum mediale. midbrain.

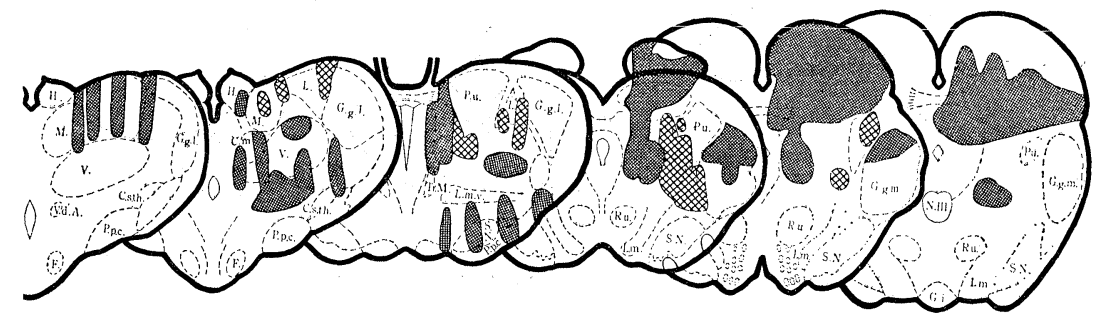

Fig. 11. The extend of the lesion in all cases are projected on a shematic drawing based upon WINKLER-POTTER's atlas. Cross stripes area indicate the region making appearance of the $\mathrm{X}$-Bundle. Solid area indicate the region having no relation to the $\mathrm{X}$-Bundle.

Potter の Pu 領域が含まれる傷で必ず変性す る (Fig. 11).

他の大脳皮質, 大脳核, 視床, 視床下核, 上 丘，内僋膝状体，黒質等の伤では変性しないの で, この新しい線維束は, $\mathrm{Pu}$ 領域（視床枕核
Nucleus pulvinal thalami）から出て中脳被蓋 外側を通り，橋核の前内僛核に，一部は後内側 に終ることが確定した。これを Tractus pul一 vino pontinus 視床枕橋核路と命名する。 


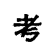

按

これまで視床からの下行路はほとんどなく20) -24), Crough (1940) 25) が Macacus Rheusus のPulvinal の内側部から中脳被蓋の深部に至 る線維群を報告している． Matano 等 (1965) 26)，は Marchi 法を用いた実験例で，上丘及 び視蓋前域から内側毛帯を貫いて橋核に入る線 維群を認めているが，主として上丘からの線維 と考光ている.

Winkler-Potter (1911) の $\mathrm{Pu}$ 領域は, Pulvinal ないしは Nucleus posterior と説明され， 下等脊椎動物の Nucleus Prebigeminalis と同 類のものと考吕られている. 尚, $\mathrm{Pu}$ 領域は, 非常に広く間脳と中脳との移行部で, Pretectal region もとの中に含まれる，この部分は動物 によって差がはげしく，注意しなければならな いところであるＰu 領域は, 一方, Nucleus posterior として Cajal 27), Miura ${ }^{28)}$, Ando (1937, 1938) 29)30). Papez(1924) 31) が使ってい るが, Winkler-Potter は “P”域で呼んでい る. Kuhlenbeck-Miller (1942) 32) は Nucleus posterior と Nucleus pretectaris とは全く異る ものであると述べている. Pretectal region は上丘と密接な関係を有しているが33)，著者の 決定し得た線維群は，上丘とは無関係である.

上丘から下行する Tractus tecto-spinalis はい ろいろな名称で呼ばれているが34446)，その起始 部は何れも上丘に大体意見の一致をみている. 著者の実験では，No. 23 は上丘の頭方，No. 21 は上丘中央部, No. 20 は上丘下方に賃を持 つが, Tractus tecto-spinalis の变性線維の数 は，余り差を認めることはできなかった，勿論 橋下端までに終末域は認められなかった。

視蓋網様体路についても意見がま台ま台であ る，著者の実験結果では，Winkler-Potter の Tractus tecto-pontinus の大部分が Tractus tecto-reticularis の主成分をなし，この視蓋橋 路の線維束から直角にこれと交叉して網様体に 向う線維が多数認められる. 更に橋核背外側縁
そ達した変性線維は, 橋底部の内側飞向って数 を減じつつその附近の網様体に終る．橋核の前 内側核, 後内側核には入らないことから, 著者 の新しい線維束とは別のものである. 次に視蓋 橋路は, Held (1890) によって初めて記され, いろいろの名称で呼ばれているが，その経路と 終末部については，大体一致している.上丘か ら出て下丘腕の内側を通って橋の辺縁部から腹 内方に, 橋の外側核ないしは, 背外側核に達す る. 著者の実験例では, 橋背外側端に達した線 維全てがそれらの核に終らず後内側核にも終 る. Matano 等 (1965) によれば，視蓋橋路に は内・外の 2 種類あり, 前者は, 上丘前部及び Pretectal region から起り，内側毛帯の外側部 を下行し，視蓋網様体核と橋核との内側部に終 ると述べている。

細幹に電極を入れる時に, 後頭葉ないしは頭 頂葉の一部を通過するので，それによって引き 起される变性を検討した。皮質橋路の中には, temporo-pontine tract (Mettller 1935) そ $\mathrm{Pa}$ rieto-pontine tract, 及び Occipito-pontine tract (Sunderland 1940) が含等れる.

Winkler (1927) は, Parieto-pontine tract は, temporo-pontine tract よりも distal に腹 側核，背外側核に終ると述べ， Borowiecki (1911), Masuda (1914) 47) らは, Winkler と 同じ立場をとっているが， Spizer \& Karplus (1907) 48), Dejerine (1901) 49), Thomas \& Dumpt (1914), Guillain (1903) 等は, Pons の前半に終ると述べている．著者の実験では， 傷が何れも深く後頭葉と頭頂葉からの線維のみ を明示できないが，これらの線維は大脳脚の腹 方部を占め，橋核前端近くで分岐し，一部は外 側核，一部は後内側核に終る. 又脳幹部の傷で 起る橋縦束の变性線維は，大脳皮質の副損傷に よると考觉ざるを得ない。

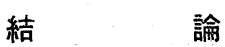

40数匹のカイウサギで実験的に次の線維群を 
みつけ，その起始，経路及び終止核を決定する ことができた。 今汔の Marchi 法と異り，軸索 変性を追求することのできる Nauta-Gygax 法 を使用したので, 終末変性によって終止核も確 かめ得た。

新しく認められた線維群は, Winkler-Potter の $\mathrm{Pu}$ 領域から出て, 中脳被蓋外側部を通り 橋核の前内側核にその殆んどが終り，一部後内 側核に終る。

$\mathrm{Pu}$ 領域つまり, 視床枕核 Nucleus Pulvinal thalami から橋核に到るこの線維群をTractus Pulvino-pointinus 視床枕橋核路と命名し, 重要 な視床の下行路であると思う。

稿を終るに当り，終止懇切な御指導と御校閲を賜 った恩師益田教授，関野講師をはじめ，教室諸先生 並びに教室員各位に深甚の謝意を表します。

\section{Abbreviations}

Aq: Aquaecuctus Sylvii

Br.c.: Bracchium conjunctivum

Br.c.v.: Bracchia conjunctiva

Br.p.: Bracchium pontis

C.a.: Commissura anterior

C.e.: Capsula externa

C.f.de.: Columna descendens fornicis

C. i.: Capsula interna

C.M.: Commissura Meynert

C.m.: Centre median.

C.post.: Commissura posterior

C.Q.a.: Corpus Quadrigeminum anticum

C.Q.p.: Corpus Quadrigeminum posticum

C.s.th.: Corpus subthalamicum

D.d.: Decussatio dorsalis Bracchii conjunctivi cerebelli

D.F.: Decussatio ventralis tegmenti or Forel.

D.M.: Decussatio Meynert

F.1.: Fasciculus longitudinalis pontisior

F.1.p.: Fasciculus longitudinalis posterior

F.r.: Formatio reticularis

F.r.b.: The b-division of the Nucleus reticulatus
G.g.1.: Ganglion geniculatum laterale

G.g.m.: Ganglion geniculatum mediale

G. i .: Ganglion interpedunculare

Ha.: Habenula

L.: Nucleus lateralis thalami.

L.1.: Lemniscus lateralis

L.m.: Lemniscus medialis

L.m.v.: Laminae medullaris ventralis

M. : Nucleus medialis thalami

m.: Nucleus medianus pontis

N.c.: Nucleus caudatus

N.HA.: Nucleus Habenulae

N.p.: Nuclei pontis

N.r.t.p.: Nucleus reticularis tegment pontis

N.III.: Nucleus nervi III

N.pr.: Nucleus reticularis proprius Lemnisci medialis

P.p.c.: Pes pecunculi cerbri

Pt.: Putamen

Pu.: Pulvinal thalami

R.: Raphe

R.op.: Radiatio optica

Ru.: Nucleus Ruber

S.gr.c.: Substantia grisea centralis

S.N.: Substantia Nigra

S.p.: Septum pellucidum

Tr.M.: Tractus Meynert retroflexus

Tr.op.: Tractus opticus

Tr.p.tr.: Tractus peduncularis transversus

V.: Nucleus ventralis thalami

v.: Nucleus ventralis pontis

V.d'A.: Vicq d'Azyr

Z.i.: Zona incerta

\section{Explanation of photomicrographs}

$\mathrm{Ph}$. 1. Showing the nuclear pattern at the level near the anterior end of the pons. Note the Nucleus medialis anterior extended at the medial region of the Fasciculus longitudinalis pontis as fanlike shape.

Ph. 2. Showing magnified cells of Nucleus me- 
dialis anterior. Arrow shows the charateristic long process of nervous cell.

Ph. 3. Showing the magnified cells of Nucleus medialis posterior. Compare morphologically with cells of Nucleus medialis anterior (Ph. 2.).

Ph. 4. Showing the positional relation among Nucleus medialis anterior Nucleus ventralis ( $v$ ) and the other (Nucleus medialis posterior involved ' $\mathrm{Pm}$ ' and 'Pl' regions).

$\mathrm{Ph}$. 5. Showing magnified cells of the 'Pm' region.

Ph. 6. Showing magnified cells of the 'Pl' region. It is difficult to differentiate between the cell of ' $\mathrm{Pm}$ ' region and these of 'Pl' region.

Ph. 7. Arrow-a shows the close relation and immediate continuation of the Nucleus reticular tegmenti with Nucleus medialis posterior.

Ph. 8. Showing Nucleus medianus. There are many small spindle shaped cells, which intramingled with Nucleus medianus and arranged dorst-ventral direction. These cells may be followed with fibrous elements of the pons.

Ph. 9. Showing the magnified cells of Nucleus medianus.

Ph.10. Showing the magnified cells, which intramingle with Nucleus medianus as metioned above.

Ph.11. Showing magnified cells of Nucleus ventralis

Ph.12. Showing magnified cells of Nucleus lateralis.

Ph.13. Showing the Nucleus lateralis and Nucleus dorsolateralis (larger cells mass).

Ph.14. Showing magnified cells of Nucleus dorso-lateralis.

Ph.15. Showing Nucleus perifasciculi longitukinalis. Note that the cells suround each branched bundles of Fasciculus longitudinalis!

Ph.16. Showing magnified cells of Nucleus perifasciculi longitudinalis.

Ph.17. The X-Bundle approaching the lateral part of the lemniscus medialis.

Ph.18. The X-Bundle penetrates through the lemniscus medialis into the Nucleus medialis anterior of the Nuclei pontis.

Ph.19. The X-Bundle extending in the Nucleus medialis anterior of the Nuclei pontis.

Ph.20. The magnified photomicrogrograph of the $\mathrm{Ph}$. 19, showing the terminal degeneration of the X-Bundle.

$\mathrm{Ph}$. 21. Showing no degeneration in the $\mathrm{Nu}-$ cleus medialis anterior of the Nuclei pontis contralateraly at the same level of Ph. 20.

Ph.22. Tractus tecto-reticularis and tecto-pontinus, descending along the lateral margin of the pons.

Ph.23. Numerous degenerated fibers of the tecto-reticularis and tecto-pontinus approaching to the dorsolateral part of the Nuclei pontis.

Ph.24. Ramification of the tractus tecto-reticularis on the way.

Ph.25. Magnified terminal degenerations bild of the tectopontine tract in the Nucleus lateralis of the pontine nuclei.

Ph.26. Ramified bundle of the tractus tectopontinus penetrating through the Nucleus lateralis of the pontine nuclei.

Ph.27. Fine degerating fibers of the tecto-pontine tract accompanying with the fibers of the parietooccipito-pontinus tract branching from the Fasciculus longitudinalis pontis.

Ph.28. The tractus parieto-occipito-pontinus ramify from the Fasciculus longitudinalis and terminate mainly the each side of Nucleus ventralis of Nuclei ponti. 


\section{References}

1) Carpenter, M.B. \& Nova, H.R.: J. Comp. Neurol. 114, 295, 1960.

2) His, W.: Arch. f. Anat. Physiol. Anat. Abt. 172, 1893.

3) Imogawa, M. \& Sakuma, S.: Acta Anat. Nipponica. : 8, 6, 631, 1935.

4) Kappers, C.U.A., Huber, G.C. \& Crosby, E. C.: Hafner Publishing Co. N.Y. 1960.

5) Lewandowsky, M.: Neur. Arb. 1, 63, 1904.

6) Reclich, D.: Monatschr. Psychiat Neur. 5, $112 \& 192,1899$.

7) Sunderland, S.: J. Anat. 74, 201, 1940.

8) Vogt, J.: Van Gorcum \& Co. N.Y. 1964.

9) Held, H.: Neurolog. Centralbl. 481, 1890.

10) Brodal, A. \& Jansen, J.: J. Comp. Neurol. 84, 31, 1946.

11) Wallenberg, A.: Anat. Anz. 26, 145, 1905.

12）益田栄，石井朗夫，田村端，新谷延幸，前田武， 森肇：解剖学雑誌，41，3，202.

13）益田栄, 石井朗夫, 田村端, 新谷延幸, 前田武, 森㲠：解剖学雑誌，41，3，203.

14) Nauta, W.J.H. \& Gygax, P.A.: Stain tech, 30, 91, 1954.

15) Bechterew, W.: Neurol. Centralbl. 3, 1885.

16) Borowiecki, S.T.: Arb. a.d. hirnanat. Inst. Zürich. 5, 39, 1911.

17) Winkler, C. \& Potter, A.: Amsterdam. 1911.

18) Messen, H. \& Olszewski, J.L.: S. Karger, New York. 1949.

19) Brodman：4）より引用

20) Bodian, A.: J. Comp. Neurol. 72, 177, 1940.

21) Bucher, V.M. \& Bürge, S.M : J. Comp. Neurol. 93, 139, 1950.

22) Collier, J. \&. Buzzard, J.: Brain 24, 177, 1901.

23) Guillery, R.W.: J. Anat. 90, 350, 1956.

24) Guillery, R.W.: Idem, 91, 91, 1957.

25) Crouch, R.L.: J. Comp. Neurol. 72, 177, 1940.

26) Matano, S., Oki, T., Zyo, K. \& Ban, t.:
Medical Journal of Osaka University. 15, 4, 1965.

27) Cajal, S.R.: 30) より引用

28) Miura, R.: Anat. Anz. 77, 1933.

29) Ando, S.: Folia anatomica Japonica, 15, 4, $361,1937$.

30）安藤洲二郎：北越医学雑誌，53，7，741 及び 53, 8, 952, 1938.

31) Papez, J.W.: J. Comp. Neurol. 56, 1, 49, 1924.

32) Kuhlenbeck, H. \& Miller, R.N.: J. Comp. Neurol. 76, 323, 1942.

33) Bucher, V.M. \& Nauta, W.J.H.: J. Comp. Neurol. 100, 287, 1954.

34) Altman, J. \& Carpenter, M.B.: J. Comp. Neurol. 116, 157, 1961.

35) Crosby, E.C. \& Henderson, J.M.: J. Comp. Neurol. 88, 53, 1948.

36) Ishii, A., Sekino, T. \& Tamura, H.: Acta Anat. Nipponica 40, 5, 3, 1965.

37) Johnson, T.N.: J. Comp. Neurol. 101, 3, $765,1954$.

38) De Lange, S.J.: Folia Neuro-Biol 13, 633, 1910.

39) Marburg, O. \& Warner, F.J.: J. Nerv. and Ment. Dis. 106, 415, 1947.

40) Munzer, E. \& Wiener, H.: Monatschr. f. Psychiatr. u. Neurol., 12, 242, 1902.

41) Nishikawa, Y.: Arb. Neur. Inst. Wien Univ., 24, 357, 1923.

42) Papez, J.W. \& Freeman, G.L.V.: J. Comp. Neurol. 56, 257, 1930.

43) Sekino, T.: Act. Anatomica Nipponica. 34, 2, 211, 1959.

44) Tasiro, S.: Z. f. Mikr, anat. Forsch, 45, 3, $321,1939$.

45) Tsai, C.: J. Comp. Neurol. 33, 173, 1925.

46) Tsai, C.: Idem, 29, 2, 217, 1925.

47) Masuda, N.: Arb. a. hirnanat. inst. Zürich, 9, 1, 1914.

48) Spitzer, A. \& Karplus, J.P.: Arbeit. aus dem Neurolog. Institut, Wien. 16, 348, 1907.

49) Dejerine, J. Anatomie des centres nerveux. Paris. 1901. 

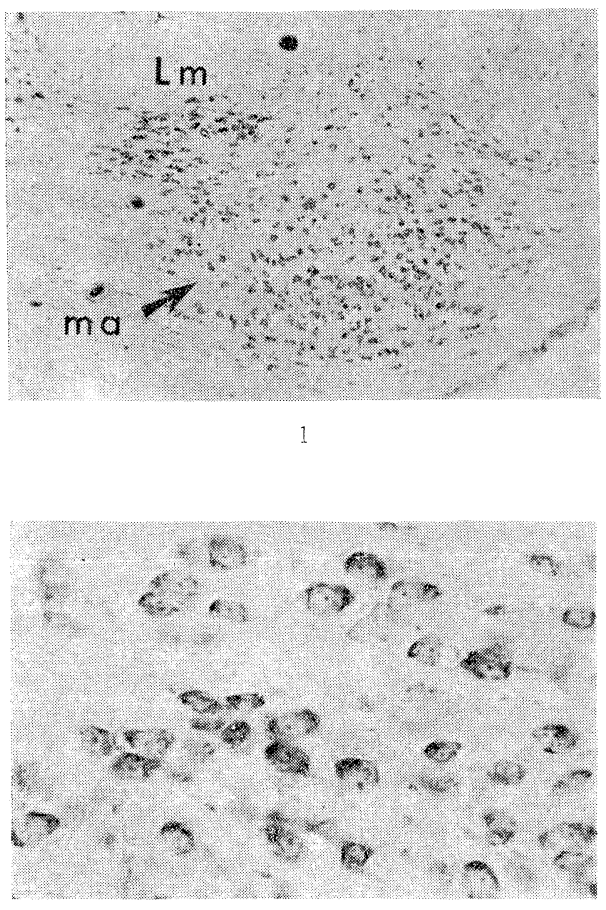

3

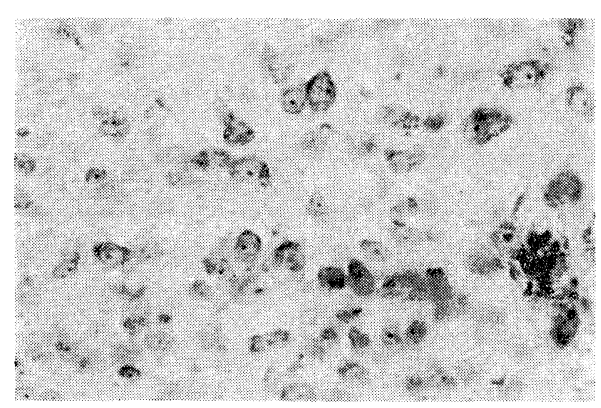

5

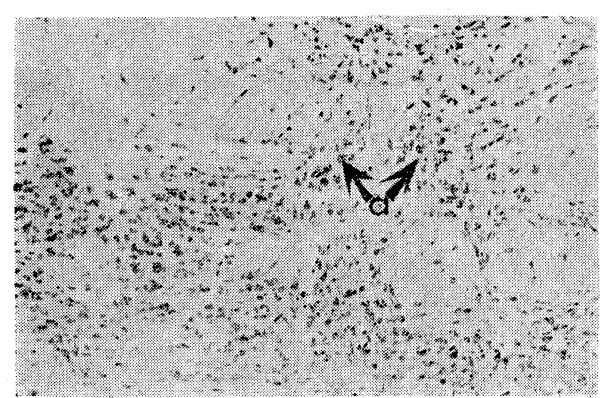

7

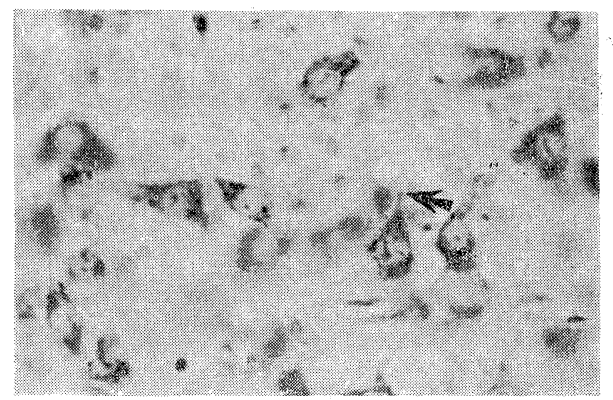

2

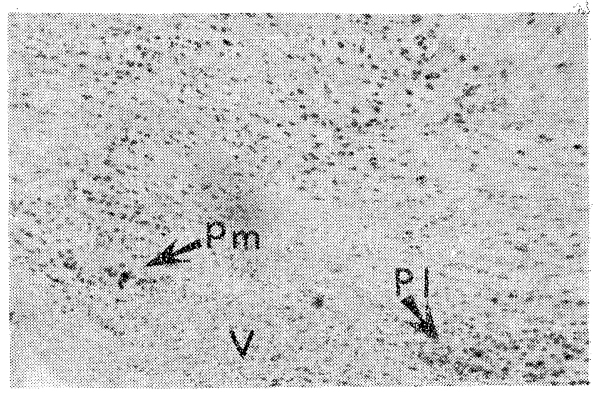

4

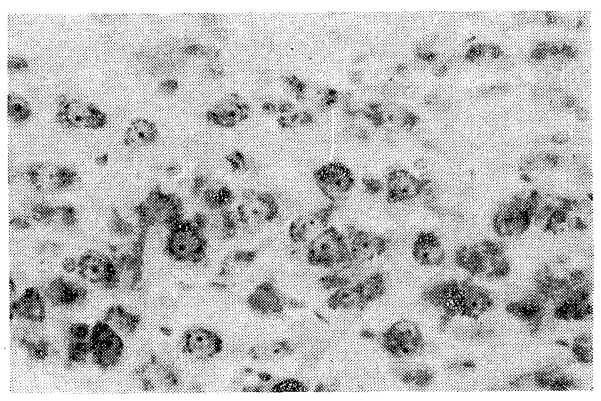

6

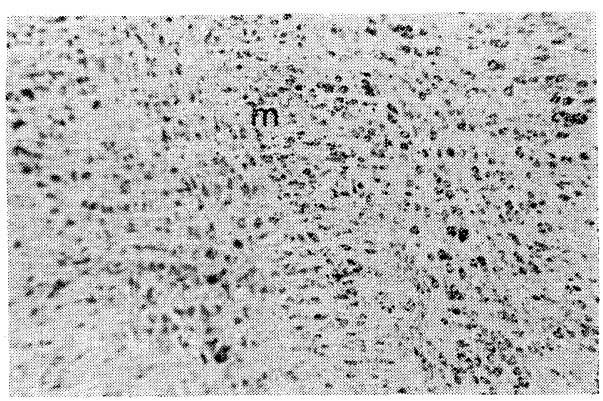

8 


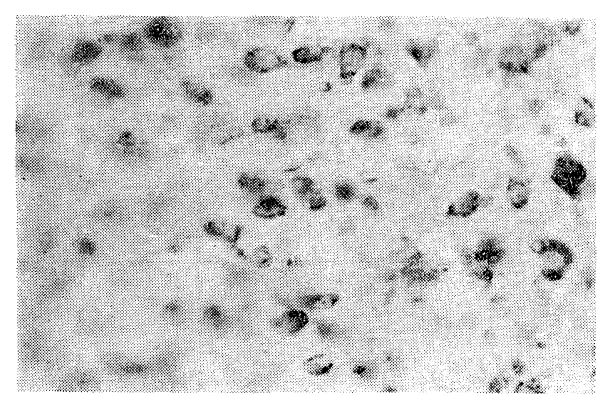

9

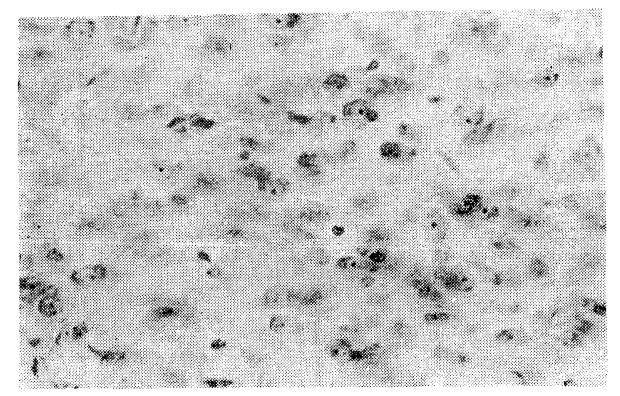

11

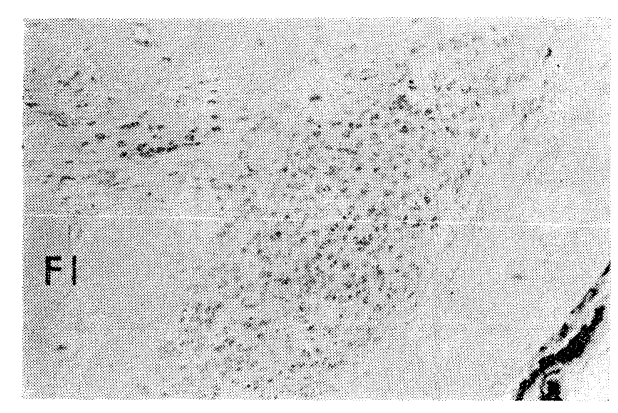

13

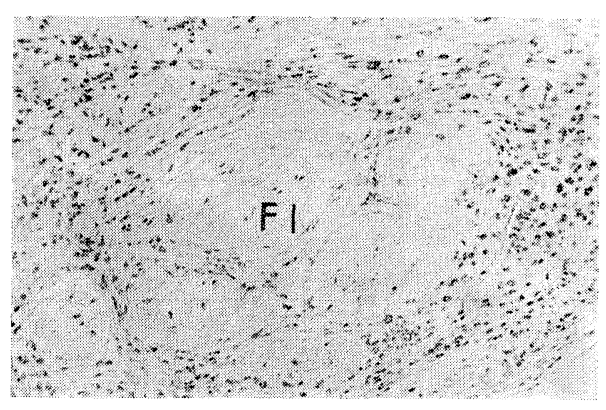

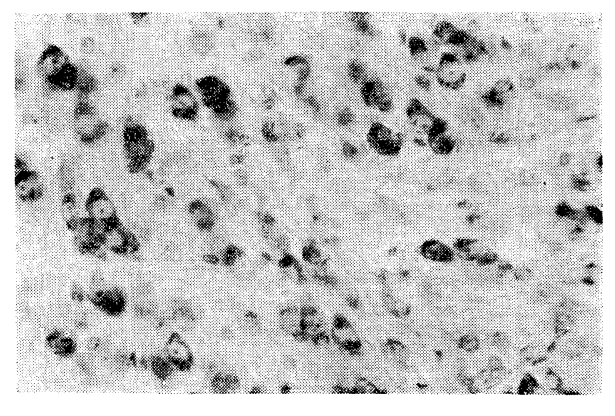

10

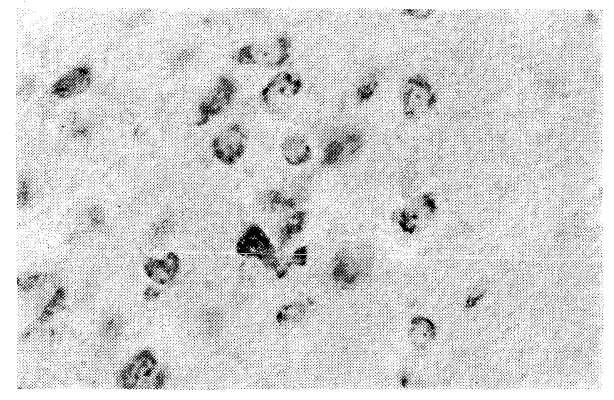

12

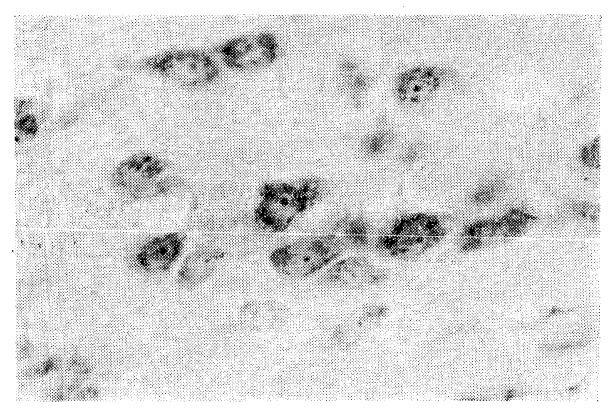

14

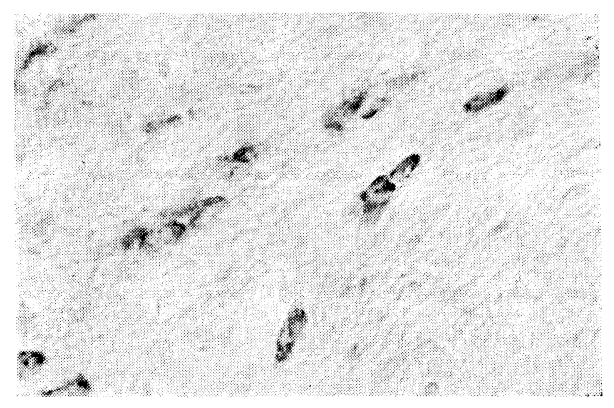

16 


\section{石井論文付図四}

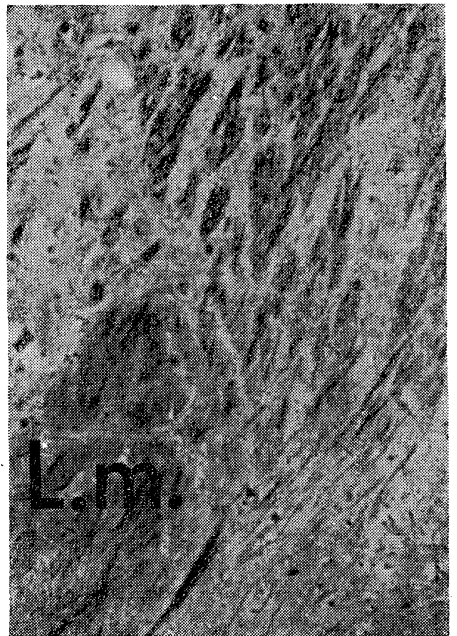

17

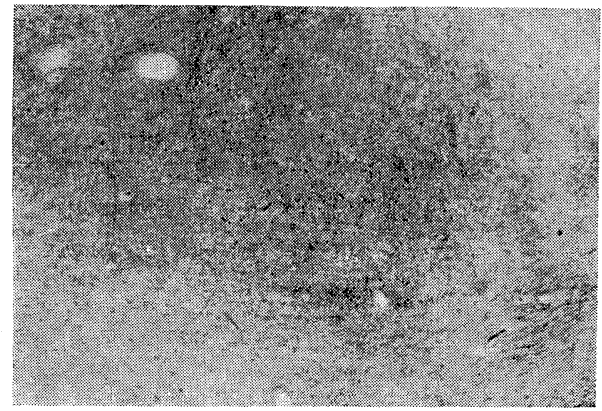

19

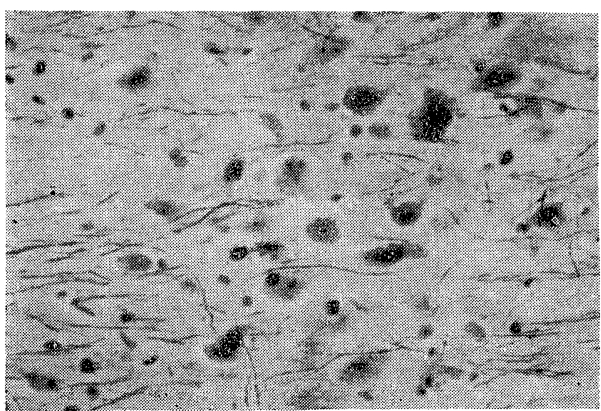

21

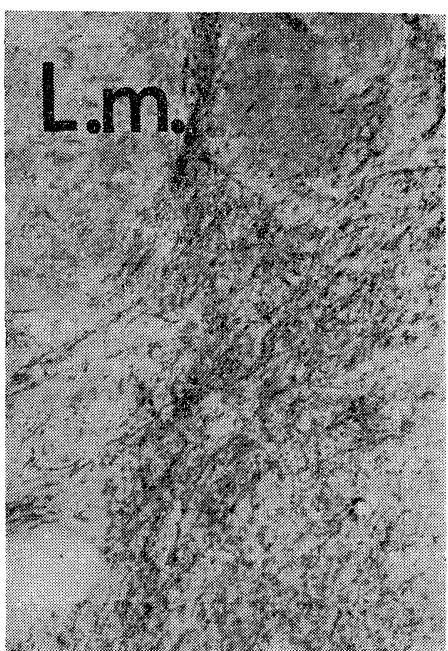

18

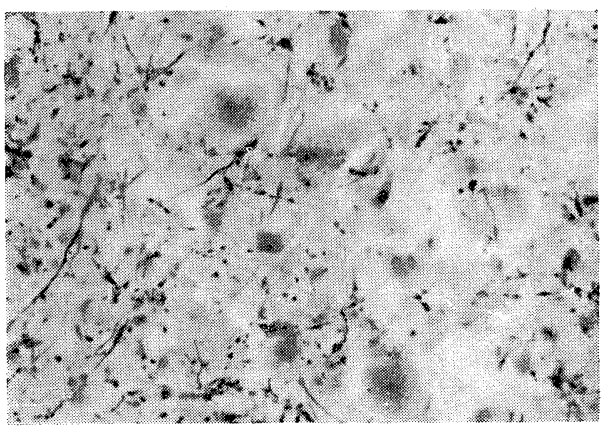

20

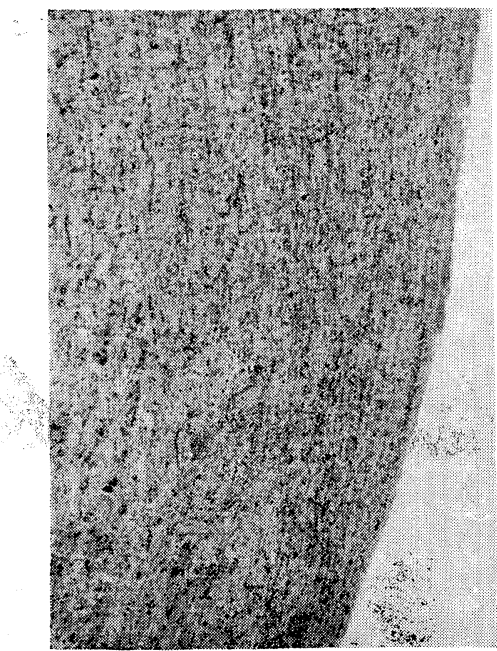

22 
石井論文付図N

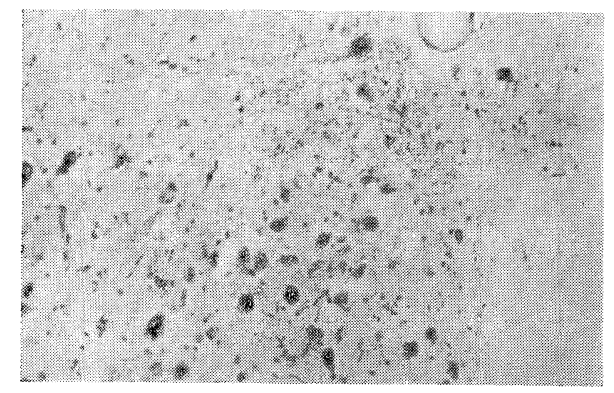

23

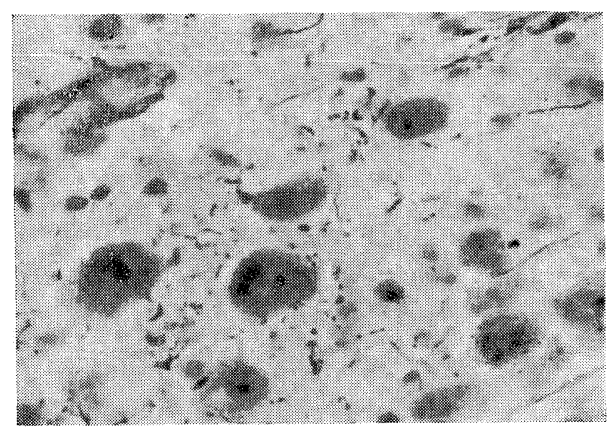

25

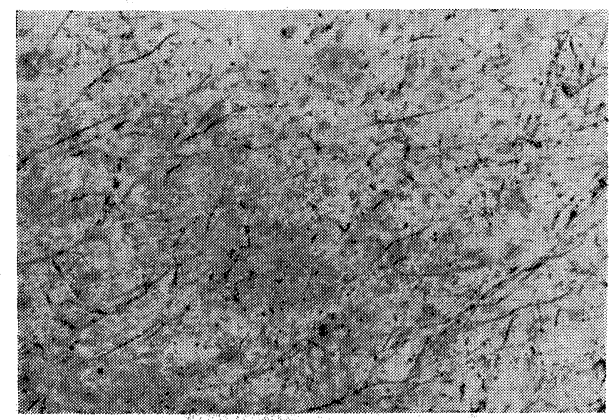

27

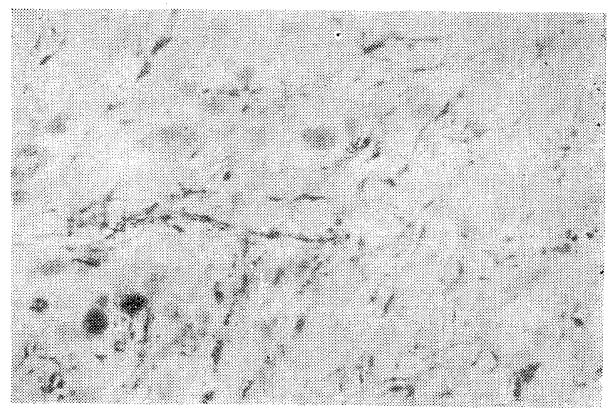

24

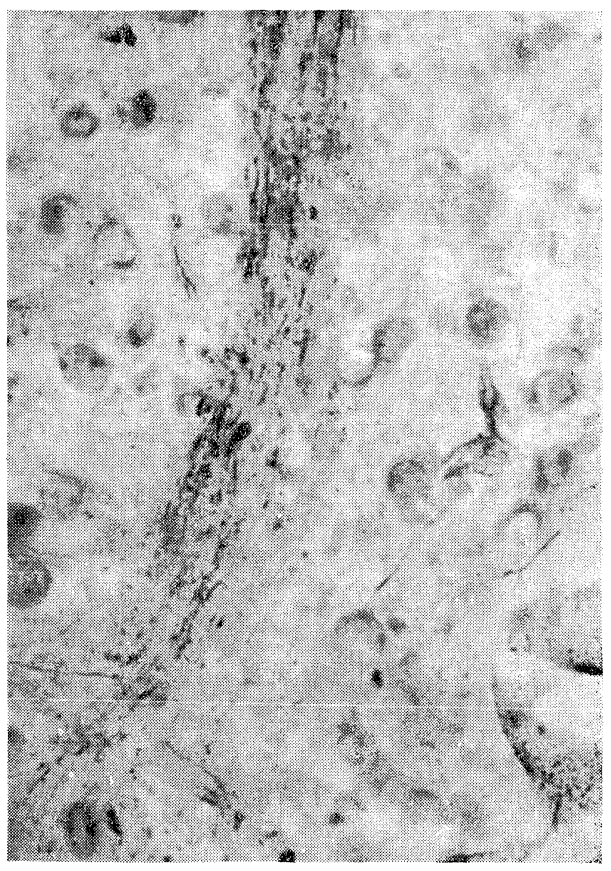

26

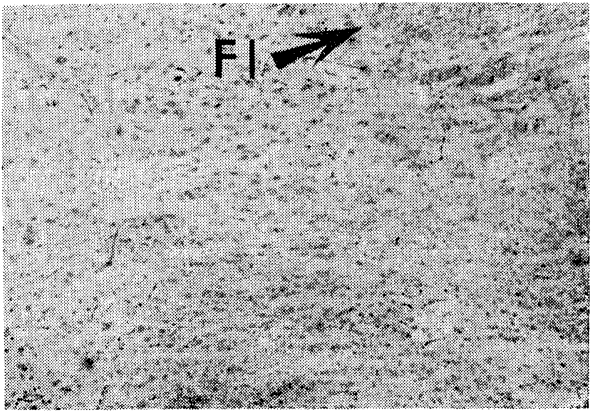

